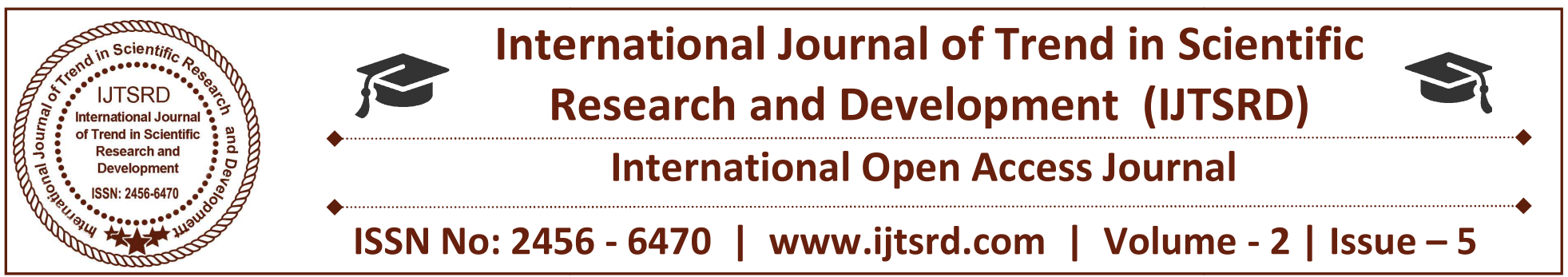

\title{
Case Comment- State Bank of India v. Indexport Registered and ORS on 30 April, 1992
}

\author{
Bhanupriya Singh Markam \\ B.A., LL.B (Hons), Indore Institute of Law \\ Indore, Madhya Pradesh, India
}

\begin{abstract}
:
The present case overrules the decision of Union Bank of India vs. Manku Narayana, while discussing Section 128 of the Indian Contract Act 1872 where the liability of the surety is co-extensive with the principle debtor and the order of the judgement of the Manku Narayan's case and the overruling of that order with the present case State Bank Of India V. Index port Registered and Ors. In which the court of law held that the decree holder can proceed against the surety even if he has not exhausted the remedy against the principle debtor or The creditor is not bound to exhaust his remedy against the principal before suing the surety, and a suit may be maintained against the surety though the principal has not been sued. With the use of Order 34 Rule 4 of Code of Civil Procedure, Order 34 Rule 5 of Code of Civil Procedure, Order 21 Rule 30 of Code of Civil Procedure, Indian Contract Act 1872 Section 128; Specific Relief Act 1963, Transfer of Property Act, 1882 -Section 68.
\end{abstract}

\section{INTRODUCTION}

The case State Bank of India V. Index port Registered and Ors satisfies all the principle conditions for a contract to be enforceable by law. The case is about the contract of guarantee and a money decree against all the defendants- respondents and a mortgage decree only against the defendant- respondent No. 2. The case discusses the coextensive liability of the surety given under Section 128 of the Indian Contract Act 1872 and the decision of Manku Narayan Case where It was held that even if the two portions of the decree are severable and merely because a portion of the decretal amount is covered by the mortgage decree, the decree holder, per force has to proceed against the

mortgaged property first ${ }^{1}$ but this decisions has been overruled by the present case State Bank Of India V. Index port Registered and Ors and explained through case analysis

\section{FACTS}

The appellant bank, that is, State Bank Of India had granted a Packing Credit Facility to the extent of Rupees one lakh to respondent No. $1 \mathrm{M} / \mathrm{s}$. Index port Registered, respondebt No.2 Shri Janeshwar Kumar Jain along with Shri Ajay Kishan Mehta( died prior filing of the suit) and now represented by respondent No.3 Smt. Savitri Devi (mother of Shri Ajay Kishan Mehta) and respondent No.4 Shri Ram Kishan, the guarantor. Respondent No. 4 executed a Deed of Guarantee in favour of the appellant Bank. Smt. Savitri Devi Respondent No.3 was impleaded in place of her deceased son as his legal representative ( Shri Ajay Kishan Mehta). As a security Respondent No.2 had also created an equitable mortgage of his shop situated in Rori Bazar, Sirsa, Haryana, in favour of the appellant ${ }^{2}$.

The appellant was obliged to file a suit against the respondents for a money decree for Rs. 33,705.22. The appellant also prayed for a preliminary decree against the respondent No. 2 with a direction that if he commits a default in payments, a final decree be passed against him with permission to the appellant to apply for a personal decree against him for any deficiency after the sale of the mortgaged property. The suit was contested by the respondents.

\footnotetext{
${ }^{1}$ Extracted from the original Judgement

${ }^{2}$ Extracted from the original Judgement
} 


\section{ISSUES RAISED}

1. Whether the said decision is correct in Manku Narayana's case.

2. the question of liability of the surety vis-a-vis the principal debtor.

\section{JUDGEMENT}

The Judgement given by the Supreme Court first declared that the decision taken in the case Union Bank of India vs. Manku Narayana was not correctly decided as it was not based on any principle of Law and in face is, Contrary to the Law and thus set aside the orders of the High Court dated 23rd May, 1990 and of the learned Additional District Judge dated 5th May, 1989 which were based on the judgement of Manku Narayana's Case .

It was held that the Decree Holder bank, that is, the appellant bank is entitled to proceed against the guarantor ( respondent No. 4) for the aforesaid decree, it is the right of the decree holder to execute the decree against the surety or principle debtor and the decree holder is not bound to exhaust his remedy against the principle debtor before suing the surety or the creditor is not bound to exhaust his remedy against the principal before suing the surety, and a suit may be maintained against the surety though the principal has not been sued ${ }^{3}$.

The security, will become useless if his rights against the surety can be so easily cut down. It was further held that such directions are neither justified under Order XX Rule 11(1) or under the inherit powers of the Court under Section 151 of the CPC to direct postponement of the execution of the decree. The decree does not postpone any execution but is simultaneous and it is jointly and severally against all defendants including the guarantor ${ }^{4}$.

\section{INTERPRETATION/ COMMENT}

The present case held that the previous judgement of the Lower Court and the High Court that were based on the case, Union Bank Of India v. Manku Narayana, having similar circumstances was wrong as it was held in that case that "since a portion of the decreed amount is covered by the mortgage, the decree-holder Bank has to proceed against the mortgaged property first and then proceed against the guarantor". Which was not based on any principle of law and in fact was contrary to the Law.

As provided in Section 128 of the Indian Contract Act 1872 , that the liability of the surety is coextensive with the principle debtor, The creditor can thus exhaust his remedy against the surety and is not bound to exhaust his remedy against the principle debtor first, as the very object of the guarantee is detected if the creditor is asked to postpone his remedies against the surety.

Under Section 140 of the Indian Contract Act 1872, the rights of the creditor will be subrogated to the surety when surety pays the decretal amount and can recover the amount from the principle debtor

\section{CONCLUSION}

In the present case only one case had the similar circumstantial situations, Union Bank of India V. Manku Narayana, in which the court held that the creditor was bound to exhaust his remedy by proceeding towards the mortgaged property and then only he could exhaust his remedy against the guarantor but the judgement was not based on any principle of law and was in fact contrary to the Law, the decree-holder is not bound to exhaust his remedy against principle debtor first he can proceed with the decree the way he likes and the very object of guarantee is dejected when the creditor is asked to postpone his remedies against the surety.

The present case has overruled the decision of the Manku Narayana's case and held that the creditor has a right to exhaust his remedy the way he likes, he is not bound to exhaust his remedy against the principle first but can directly sue surety as principle and surety's liability is coextensive in nature, and the creditor may not even sue the principle, the surety can recover the amount it paid to the Creditor from the Principle under Section 140 of the Indian Contract Act 1872 where the Creditor's rights are subrogated to Surety.

\footnotetext{
${ }^{3}$ Potlock \& Mulla on Indian Contract and Specific Relief Act, Tenth Edition, at page 728

${ }^{4}$ Extracted from the original Judgment
} 